\title{
ФОРМИРОВАНИЕ ОБОЗНОЙ СЛУЖБЫ РУССКОЙ АРТИЛЛЕРИИ В ПЕРВОЙ ПОЛОВИНЕ ХVIII-ГО ВЕКА
}

\section{CREATING OF TRANSPORTATION SERVICE OF THE RUSSIAN ARTILLERY IN THE FIRST HALF OF XVIII-TH CENTURY}

P. Amochaev

Summary: Eighteenth century played an important role in the history of the Russian armed forces. It was the epoch of formation of the Russian regular troops. There was impossible to create a standing army without organization effective conveyance service. At that time, when almost all military industry in the country was subordinate to the Artillery department, artillery means of transportation have got a special importance. What were the reasons that determined formation of the transport troops of the Russian artillery, what stages this process did contain, what were the distinguishing features that it had in this period and what was its importance in history? These are the questions, that the author tries to answer.

Keywords: army baggage train, military conveyances, war drivers, transportation service, Russian artillery, army of Peter the Great.
3 начимость транспортного обеспечения для вооружённых сил трудно переоценить, тем удивительнее, что службы, занимающиеся столь важным делом, нечасто становились объектами исторического исследования. Цель данного труда - хотя бы отчасти восполнить существующий пробел.

Темой работы является артиллерийский фурштат русской армии. Фурштатом принято было называть обоз воинской части и обслуживающий его персонал. Такие команды существовали во всей армии, но артиллерийский фурштат обладал рядом важных отличий. Если в остальных родах войск отсутствие обоза могло вызвать лишь некоторое ограничение в маневренности, то артиллерия, без средств перевозки своей материальной части, вообще не могла существовать. Кроме того, не стоит забывать, что в XVIII веке артиллерия рассматривалась не только как род войск, но и «...яко движимый арсенал и магазин войска» [1, С. 159]. Пехотным полкам полагалось иметь при себе запас пороха всего на 50 выстрелов, весь остальной порох находился в распоряжении артиллеристов [2, Л. 4]. Так что, артиллерийский фурштат играл важную роль в истории не только отечественной артиллерии, но и всех российских вооружённых сил.

Причиной недостаточной освещённости данного вопроса в научной литературе, вероятно, является то, что
Амочаев Павел Александрович,

Соискатель, Санкт-Петербургский государственный университет, преподаватель, Академия управления городской средой, градостроительства и печати,

Санкт-Петербург

amochayeff@yandex.ru

Аннотация: Восемнадцатое столетие сыграло в истории отечественных вооружённых сил важную роль. Оно стало эпохой формирования российских регулярных войск. Становление постоянной армии было бы невозможно без создания эффективной обозной службы. В условиях, когда почти всё военное производство в стране было сосредоточено под управлением артиллерийского ведомства, особое значение приобретала артиллерийская служба транспортного обеспечения, более известная как фурштат. Какими факторами было предопределено формирование артиллерийского фурштата русской армии, какие этапы он прошёл на пути этого формирования, какими отличительными чертами он обладал в первой половине XVIII-го века и какова его историческая значимость? Вот вопросы, на которые пытается найти ответ автор, несмотря на скудость источников и слабую проработку темы в научной литературе.

Ключевые слова: 0боз, фурштат, фурлейт, фурман, служба военных сообщений, русская артиллерия, армия Петра I.

он относится к предмету, занимающему место на стыке двух направлений военно-исторической науки: истории артиллерии и военных сообщений. Дореволюционные исследователи истории артиллерии (Д.П. Струков, В.Ф. Ратч, М.Д. Хмыров), как правило, сосредотачивались на рассмотрении вопросов совершенствования материально-технической части и органов управления. Лишь Н.Е. Бранденбург несколько проливает свет на процесс рождения регулярного фурштата [3]. Советские историки больше внимания уделяли социальным и политическим аспектам в развитии артиллерии, но и в их трудах фурштат упоминается лишь вскользь. И.С. Прочко сообщает, что Пётр I ввёл постоянные команды для перевозки орудий [4, С. 82], а Л.Г. Бескровный добавляет, что эти команды получили название фурштата [5, С. 44].

Авторы, изучавшие историю военных сообщений, начинают подробное повествование со времён постройки в России железных дорог, о XVIII-м же столетии сообщается лишь тот факт, что в 1708 году была учреждена должность генерал-вагенмейстера - начальника обозной службы [6, С. 8]. В последнее время появились работы, в которых формирование артиллерийского фурштата рассматривается, более подробно. Наиболее полно проблема раскрыта в диссертации Ю.Е. Манойленко, однако выбранный формат не позволил автору уделить данному вопросу достаточно внимания [7]. 
Армия допетровской России не знала постоянных обозных частей. Перевозочные средства и извозчики нанимались по мере необходимости и на ограниченный срок. Как правило, перед началом военной кампании, Ближняя канцелярия указывала Земскому приказу количество необходимых перевозочных средств, место их сбора и сроки, после чего Земский приказ передавал этот указ воеводам в уезды и направлял к месту сбора стольников, для контроля за выполнением указа [3, С. 227]. Лошади собирались на нескольких станциях расположенных поблизости от места хранения артиллерийских припасов, где имелись необходимые пастбища.

Ситуацию изменил указ Петра I, в декабре 1706 года. Царь приказал отпустить нанятых весной предыдущего года извозчиков и впредь использовать вместо них рекрут [8, С. 362]. Законодатель не раскрыл причин такого решения, исследователи же выдвигают разные гипотезы.

Прочко утверждает, что основной причиной было частое бегство извозчиков с поля боя [4, С. 82]. Бранденбург, основываясь на документах архива Музея артиллерии, приходит к выводу о несостоятельности прежней системы транспортировки, так как, во-первых, она ставила артиллерию в зависимость от Земского или Ямского приказов, которые ведали комплектованием перевозочных средств, а так же местных воевод и помещиков, которые должны были обеспечивать их непосредственный сбор; во-вторых, формирование таким образом обоза заново под каждую конкретную военную задачу, фактически ставило под угрозу срыва выполнение самой задачи, в случае малейшей нестыковки, которых, на практике, оказывалось множество из-за нерадивости слабо контролируемых подрядчиков [3, С. 229]. Зачастую крестьяне не горели желанием покидать родные уезды и направляться в зону боевых действий, поэтому вскоре начинали саботировать царские поручения и попросту выбрасывать военные грузы в поле [7, С. 119]. Конечно можно было стимулировать их усердие повышением платы, но это ударило бы по бюджету.

Важной предпосылкой можно считать то, что в данный период в российской армии начинают активно практиковаться рекрутские наборы. Такой способ комплектования наполнил армию большим количеством вчерашних крестьян, слабо знакомых с военным делом, зато хорошо умеющих ухаживать за лошадьми. Архивные данные свидетельствуют, что применение рекрут в качестве извозчиков практиковалось в русской армии и ранее, а царский указ, скорее, лишь законодательно зафиксировал давно устоявшееся положение. Например, некий Пётр Папутьев в своей челобитной упоминает, что служит в фурлейтах с 1702 года [9, Л. 163].
По поводу численности и организации артиллерийского фурштата в первые годы его существования, трудно сказать что-то определённое. Указом 1706 года предписывалось лишь «быть в артиллерии и в драгунских и в солдатских полках рекрутам извозчикам шести тысячам человек, и давать им по пяти рублей человеку на год». То есть изначально артиллерийский фурштат не был выделен из общеармейского организационно, но произошло это не позднее мая 1707 года, когда приказано было объединить артиллерийских фурлейтов в 13 команд [7, С. 117].

В 1712 году русская артиллерия получает штатное расписание, по которому артиллерийский фурштат состоял из шталмейстера (в чине армейского капитана), двадцати фургеров (или фурлейтских поручиков), шестидесяти фурмейстеров (о которых сказано, что «оные суть яко сержанты в роте»), ста двадцати унтер-фурмейстеров (капралов) и 2000 фурлейтов (извозчиков), сведённых в 20 команд. При этом жалование извозчикам было поднято с 5 до 6 рублей в год [8, С. 798]. Таким образом, артиллерийский фурштат был выделен из общеармейского и, судя по табели, состоял в подчинении полкового штаба артиллерийского полка. Чем определялась численность извозчиков в 2000 человек не совсем ясно. Скорее всего, эта цифра была получена путём округления предполагаемых потребностей и никогда не соответствовала действительному числу. К 1714 году удалось укомплектовать лишь 12 команд в составе 1255 человек и 1986 лошадей [5, С. 44].

В 1727 году, когда во главе русской артиллерии оказался педантичный немец И.Я. Гинтер, была предпринята попытка вычислить точное число лошадей и людей, необходимых для перевозки пушек и прочих артиллерийских принадлежностей. За основу была взята грузоподъёмность среднестатистической лошади, которую определили в десять пудов. Рассчитав общий вес всего движимого имущества, Гинтер пришёл к выводу, что для его транспортировки будет необходимо 5370 лошадей, а для ухода за ними 2685 фурлейтов (по одному, на пару лошадей). Весь личный состав фурштата Гинтер предлагал разделить на 22 команды во главе с фурлейтскими поручиками [10, Л. 87]. Однако данный проект не был утверждён.

Правительство стремилось минимизировать военные расходы и в 1730 году предложило сократить фурштат до 8 команд из 938 человек и 1600 лошадей [7, С. 143]. Однако начавшаяся война с Турцией заставила руководство страны на время отказаться от планов по сокращению фурштата и вновь расширить его до 16 команд из 2778 человек и более 5 тысяч лошадей в 1737 году. Лишь после окончания войны Кабинет министров вернулся к программе сокращения 1730-го года. Избы- 
точные солдаты были отправлены на службу в гарнизоны, а лошади розданы в полки.

В оперативном отношении шталмейстер подчинялся командиру артиллерийского полка, а в административном - находился под руководством артиллерийского обер-кригс-комиссара. В 1730 году была предпринята попытка передать фурштат в подчинение недавно учреждённой обер-цейхвартерской конторы [11, С. 150], но в 1737 году он вновь переходит в ведение обер-кригскомиссара [11, С. 185].

В 1757 году, когда русская артиллерия получила новые штаты, она уже состояла из двух полков и фурштат пришлось вывести из подчинения командира полка. Так артиллерийский фурштат превратился в самостоятельное воинское подразделение в составе артиллерийского ведомства российской армии. Должность шталмейстера стала подполковничьей, в помощь ему был придан унтер-шталмейстер (майор), а в их подчинении теперь оказалось три капитана, три поручика, три подпоручика и три прапорщика, каждый из которых возглавлял одну из 12 команд в составе двух фурмейстеров, четырёх унтерфурмейстеров и 141-142 фурлейтов [12, С. 363].

Необходимо отметить, что данный фурштат предназначался для обслуживания нужд исключительно двух артиллерийских полков. Транспортировку же артиллерии обсервационного корпуса и «секретных» Шуваловских гаубиц предполагалось поручить особым фурштатским подразделениям, учреждения которых П.И. Шувалов добивался в 1758 году. Этот проект прекратил своё существование вместе с самим корпусом в 1760 году, а штат 1757 года оставался в силе до конца столетия.

Преимущества использования рекрут вместо наёмных извозчиков очевидны. Это повлекло за собой не только экономические выгоды (ведь фурлейты из рекрут получали жалование даже ниже рядовых солдат армейской пехоты), но и повышение дисциплины. Наёмный извозчик не только обходился казне дороже (по рублю и четырнадцати с четвертью копеек в месяц $[13$, Л. 7]), но и вовсе мог отказаться сотрудничать, что и произошло, например, в марте 1727 года, когда поручику Петлингу так и не удалось найти извозчиков для перевозки пушек из Выборга в Санкт-Петербург «понеже таких тягостей вести нехотят» $[14$, Л. 1]. Дело в том, что, поскольку изначально фурштат был структурным подразделением артиллерийского полка, он не обслуживал арсеналы и заводы. Лишь в 1738 году были учреждены особые фурштатские команды из поручика, фурмейстера, двух унтер-фурмейстеров и 50 фурлейтов каждая, для обслуживания нужд Санкт-Петербургского и Московского арсеналов, а так же команду из одного унтер-фурмейстера и 16 фурлейтов для работы на пороховых заводах [12, С. 245].

Кроме того, выполнение обязанностей извозчика почти не требовало от новобранца специальной подготовки, так как управляться с лошадьми умел каждый крестьянин, зато, за время службы в фурлейтах, он постепенно приобретал навыки необходимые солдату и, при необходимости, его можно было поставить в строй, а на освободившееся место назначить нового рекрута. Впрочем, в армейских полках численность извозчиков была относительно невелика и данный способ подготовки кадров не получил особого распространения. Если первоначально прибывшего рекрута стремились определить в извозчики на два-три года, то после 1735 года эта практика была прекращена и прибывающих рекрутов сразу расписывали по ротам [15, С. 71]. Иначе обстояло дело в артиллерии.

В августе 1725 года артиллерийское руководство направило командиру артиллерийского полка указ: «Понеже из присылаемых в Главную артиллерию из московской артиллерийской канторы месячных и недельных репортов усмотрено что есть в Москве при артиллерии рекрут, а обретаются в артиллерийской службе фурлейты которые по долговременной службе давно уже достойны быть в фузелерах, того ради оные обретающиеся в Москве при артиллерии рекрут сколько их есть написать в фурлейты по разсмотрению артиллерии генераллейтенанта и кавалера господина Гинтера и определить им фурлецкое жалование, а оных фурлейтов которые давно при артиллерии служат написать же толикое число колико оных рекрут в фурлейты написано будет, в фузелеры в полевую артиллерию выбрав их здоровых и молодых людей которыеб могли фузелерскую службу нести и росписать оных по ротам и впредь когда присылаться будут рекруты в комплект то тех приверстывать кроме шляхетства в фурлейты а из фурлейтов комплектовать фузелерские роты, дабы и фурлейты за службы свои в произведении и награждении оставлены не были чего в Главной артиллерии смотреть накрепко» [16, Л. 249].

Данным приказом устанавливался определённый порядок прохождения службы нижними чинами артиллерии. Новоприбранный рекрут зачислялся в фурлейты, где проходил начальную военную подготовку, осваивал азы солдатской службы, после чего его переводили в фузилеры и начинали обучать пушкарскому ремеслу, затем он, наконец, получал чин канонира, то есть становился рядовым артиллеристом. Такая многоступенчатая система отбора и подготовки кадров объяснялась сложностью служебных обязанностей артиллеристов и отсутствием у артиллерии собственной базы для первичной подготовки рекрут в виде рекрутских депо или гарнизонных полков. 
Впрочем, подобный порядок обучения предписывался далеко не всем новобранцам. Так, уже в самом приказе оговаривалось, что представителям шляхетства служба в фурлейтах не грозила, они поступали на обучение в артиллерийскую школу, доступ в которую так же был открыт детям артиллеристов и мастеровых. Кроме того, к вышеприведённому приказу вскоре последовало дополнение: «...ежели из вольницы присылать будут в фурлейты не писать, а определять таковых в фузелеры, токмо разве кто из рекрут пришлется. А ежели и из вольницы присылатца будут такие которые в фузелерах быть не годны и таковых не принимать...» [16, Л. 854 об.]. Необходимо отметить, что данная система подготовки кадров не учитывала некоторых объективных трудностей и нуждалась в доработке, на что и указывал И.Я. Гинтер в своём доношении в Главную артиллерию от 9 февраля 1726 года: «...по рассмотрению моему явилися немногие из фурлейт кто к службе годны и за старостию им тое службы нести трудно; а помянутые рекруты ещё люди молодыя и обретаются уже третий год при артиллерии... так же и экзерциции обучены; Того ради по мнению моему расписал некоторых годных из фурлейтов из денщиков из рекрутов в фузелеры такое ж число какое ныне рекрут обретается; а остальных рекрут назначил в фурлейты о чем подлинно прилагается при сем имянной список...». В приложенном списке означены фамилии ста фузилёров, при этом 5 из денщиков, 24 из фурлейтов, 71 из рекрут, а 29 рекрут зачислены в фурлейты [16, Л. 588].

Приведённая переписка показывает, что, с первых же лет существования артиллерийского фурштата, на него, кроме его основных обязанностей, была возложена дополнительная и очень важная функция по подготовке кадров. В 1757 году была предпринята попытка закрепить данный порядок законодательно [12, С. 361]. П.И. Шувалов предложил в мирное время незадействованных лошадей распродавать, а фурлейтов использовать для работ при арсеналах, параллельно обучая военному делу, чтобы, при необходимости, заменять ими выбывших из строя артиллерийских фузилёров.

Фурштат стал кузницей кадров не только для канонирских рот, но и для многих других структурных подразделений артиллерийского ведомства. Прежде всего, фурлейту предоставлялась возможность сделать карьеру в самом фурштате и заслужить нашивки унтер-фурмейстера, а затем и фурмейстера. Правда такая карьера малого кого могла привлекать, так как фурмейстер хотя и исправлял обязанности ротного сержанта, но жалование получал равное рядовому солдату полевого пехотного полка.

У рекрута владеющего ремеслом была возможность перевестись в мастеровые. Так, например, фурлейты
Козьма Вдовин и Максим Горин оказались весьма искусны в плотницком деле, за что и были отобраны цейхвартером Суитиным для работы в московском арсенале $[17$, Л. 1]. А когда в петербургском арсенале выявилась нехватка «пильников деревянного дела», то, для обучения этому ремеслу, было отобрано трое фурлейтов [18, Л. 132].

Если рекрут, паче чаяния, владел грамотой, то его ждала более привлекательная карьера канцелярского служащего [19, Л. 238]. Ну а если он, кроме того, ещё и достаточно сметлив и находчив, то вполне мог рассчитывать на место «купчины», то есть снабженца [19, Л. 216]. Фурлейты же, не обладающие специальными навыками, могли быть откомандированы для выполнения менее квалифицированной работы, например работы сторожа $[20$, л. 20].

В бою на фурлейтов, как и на всех нестроевых, возлагалась обязанность выноса раненых с поля боя, чтобы строевые чины не отвлекались от ведения огня [15, С. 57].

Пожалуй, самым необычным способом применения фурлейтов можно считать использование их в качестве гребцов. Дело в том, что для переправы через Неву при Главной артиллерии содержался вельбот и несколько небольших лодок - вереек, для обслуживания которых в августе 1726 года велено было сформировать команду из шести гребцов во главе с матросом. Эту команду запрещено было отвлекать в иные работы «дабы они к водному хождению могли обыкнуть» [20, Л. 103].

Шанс сделать быструю карьеру фурлейту предоставляла возможность стать денщиком при одном из офицеров. Проявив определённую расторопность при исполнении своих служебных обязанностей, вчерашний фурлейт мог надеяться на хорошие рекомендации и содействие в дальнейшем продвижении по службе со стороны своего патрона. Конечно, это зависело от влиятельности офицера, но не меньшее значение имели и личные качества самого солдата. Так, например, штаблекарь Гакман оказался недоволен услугами своего денщика Ивана Проскурина и потребовал отослать его обратно в фурлейтскую команду [20, Л. 17]. Зато гораздо больше повезло денщикам Я.В. Брюса. Покидая пост генерал-фельдцейхмейстера, он дал отличные рекомендации большинству своих денщиков, благодаря которым шестеро из них стали фузилёрами, один произведён в капралы, один занял место цейхшребера (писаря) при петербургском арсенале [16, Л. 757], а Никифор Ионин за одиннадцать лет пребывания в денщиках «обучался не токмо грамоте и писать, но и арифметике и части геометрии» [16, Л. 731], за что был произведён сразу в фурьеры. То есть, выполняя обязанности денщика при образо- 
ванном офицере, солдат имел возможность повысить и уровень своей грамотности, что серьёзно повышало его шансы на ускоренное продвижение по службе.

Офицерский состав фурштата был представлен шталмейстером и несколькими фурлейтскими поручиками, возглавлявшими отдельные команды. Обращает на себя внимание тот факт, что многие офицеры нестроевой службы в артиллерии начинали свою карьеру в фурштате. Например, комиссар Семён Хитров и обер-комиссар Лев Аристов прежде были фурлейтскими поручиками, а казначей Василий Арсеньев - шталмейстером. Кстати, на место последнего был назначен Алексей Гаврилович Марков, карьера которого довольно типична: в 1705 году он был выпущен из артиллерийской школы фурьером полевой артиллерии, а его первой офицерской должностью была должность фурлейтского поручика, после окончания Северной войны Алексей Гаврилович возглавил московский арсенал, а через два года переведён в Петербург комиссаром на пороховой завод, где и служил, пока не вернулся в фурштат, но уже на должность его начальника. Место фурлейтского поручика так же было первой офицерской должностью для Ивана Парасукова и Семёна Путковского, до того служивших сержантами в полевой артиллерии [18, Л. 230]. Вышесказанное свидетельствует, что фурштат был для артиллерии не только средством транспортировки, но и кузницей кадров.

Что касается лошадей, попадавших на службу в артиллерию, то нам известно, что все они были меринами, покупавшимся у частных лиц или на ярмарках. Например, в апреле 1730 года фурлейтский поручик Василий Секерин получил из казны 1600 рублей на закупку 200 лошадей на Макарьевской ярмарке [18, Л. 40]. Менять лошадей полагалось через пять лет службы [21, Л. 1 об.], либо если она более не могла нести службу по состоянию здоровья. В обоих случаях таких лошадей продавали, но, конечно, по более низкой цене. Так в феврале того же 1730 года другому фурлейтскому поручику, Михаилу Луговскому, удалось выручить за четырёх престарелых лошадей всего 10 рублей и 75 копеек [22, Л. 10]. Служба этих лошадок была очень трудной, о чём можно судить по тому факту, что все лошади предназначавшиеся для продажи были больными или даже имели травмы, а некоторые до такой продажи просто не доживали, падая прямо в упряжи. Впрочем, высокая смертность конского состава артиллерии объяснялась не только тяжестью службы, но и изначально низким качеством этого состава. Артиллерийские закупщики часто встречали препятствие со стороны более влиятельных покупателей, «губернаторов и комендантов» [3, С. 231]. Поэтому не стоит удивляться, что из 200 лошадей, приобретённых поручиком Секериным на Васильевской ярмарке в 1721 году, пять пали ещё в пути, а остальные оказались «...все средней руки и много мелких и к походу негодных» [23, л. 32 об.].

Конским составом фурштат обязан был обеспечивать и армейские полки, которым полагалось иметь полковую артиллерию, что доставляло артиллерийскому руководству немало проблем. Например, в 1724 году командование черниговского пехотного полка затребовало лошадей на замену присланным ранее «...которые от той работы и бескормицы захудали и пали» [24, Л. 65 об.]. Артиллерийская канцелярия заподозрила неладное и потребовала предоставить шкуры указанных лошадей с артиллерийским клеймом.

Особую проблему представляло содержание такого количества лошадей, особенно в мирное время, когда особой потребности в них не было. О важности этой проблемы свидетельствует тот факт, что 4 декабря 1724 г. Пётр I собственноручным указом повелел «... о лошадях артиллерийских сыскать способ, а чтоб не всегда держать, например часть на монастыри и архирейские домы, часть или две на всю армию по полкам роздать в их употребление» [25, Л. 49].

В завершение, необходимо отметить, что, хотя фурштат и относился к артиллерии, но имел статус равный гарнизонным частям, о чём можно судить не только по размеру оклада фурштатских служащих (например фурлейт получал всего 6 руб. в год, в то время, как солдаты полевых полков получали по 10 руб. 80 коп.), но и по тому, что они носили армейские чины и униформу.

Изначально казённые извозчики установленной формы не имели вовсе [26, Л. 51], а с 1728 года фурштатский мундир состоял из серого суконного кафтана с васильковыми обшлагами и воротником, такого же камзола, штанов из козлиной кожи, двух пар сапог и картуза $[18$, л. 54].

Учреждение в русской армии артиллерийского фурштата в начале XVIII века оказалось весьма своевременным. Это позволило не только сэкономить значительную часть казённых средств, но и существенно повысить, как степень мобильности отечественной артиллерии, так и уровень боевой подготовки её служителей. Отличительной особенностью развития артиллерийской обозной службы в России первой половины XVIII-го столетия являлось то, что, в условиях низкого уровня образования в стране, ей пришлось решать задачи по начальной подготовке артиллерийских кадров. В целом же, создание новой структуры, по существу, стало новым шагом на пути преобразования русской артиллерии в самостоятельный род войск. 


\section{ЛИТЕРАТУРА}

1. Преображенский А.А. Законодательство Петра І. М.: Юридическая литература, 1997. 880 с.

2. Архив Военно-исторического музея артиллерии, инженерных войск и войск связи. Фонд 2. Оп. 2. Д. 48.

3. Бранденбург Н.Е. Материалы для истории артиллерийского управления в России. «Приказ артиллерии». (1701-1720 г.). СПб.: типография Артиллерийского журнала, 1876.571 c.

4. Прочко И.С. История развития артиллерии: С древнейших времён и до конца ХІХ в. СПб.: ПОЛИГОН, 1994. 495 с.

5. Бескровный Л.Г. Русская армия и флот в XVIII веке: (Очерки). М.: Воениздат, 1958. 645 с.

6. Михеев Ю.З., Чугунов В.Д. Военные сообщения. М.: 000 ИК «Трейдмастер», 2008. 246 с.

7. Манойленко Ю.Е. Русская артиллерия в первой трети XVIII века: диссертация на соискание учёной степени кандидата исторических наук: 07.00.02. СПб., 2010. $211 \mathrm{c}$.

8. Полное собрание законов Российской империи. 1-е издание. СПб. 1830. Т. 4.

9. Архив Военно-исторического музея артиллерии, инженерных войск и войск связи. Фонд 2. Оп. 6. Д. 10.

10. Архив Военно-исторического музея артиллерии, инженерных войск и войск связи. Фонд 2. Оп. 3. Д. 99.

11. Струков Д.П. Главное артиллерийское управление: Исторический очерк. / Столетие Военного министерства: 1802-1902. В 13 т. СПб.: Типография товарищества М.0. Вольф, 1902. Т. 6. Ч. 1. Кн. 1. 533 с.

12. Полное собрание законов Российской империи. 1-е издание. СПб. 1830. Т. 43. Книга штатов.

13. Архив Военно-исторического музея артиллерии, инженерных войск и войск связи. Фонд 2. Оп. 8. Д. 438.

14. Архив Военно-исторического музея артиллерии, инженерных войск и войск связи. Фонд 2. Оп. 8. Д. 402.

15. Баиов А.К. Русская армия в царствование императрицы Анны Иоанновны. Война России с Турцией в 1736-1739 гг. СПб.: Электро-типография Н.Я. Стойковой, 1906. 556 c.

16. Архив Военно-исторического музея артиллерии, инженерных войск и войск связи. Фонд 2. Оп. 3. Д. 86.

17. Архив Военно-исторического музея артиллерии, инженерных войск и войск связи. Фонд 2. Оп. 8. Д. 311.

18. Архив Военно-исторического музея артиллерии, инженерных войск и войск связи. Фонд 2. Оп. «Генеральное повытье». Д. 149.

19. Архив Военно-исторического музея артиллерии, инженерных войск и войск связи. Фонд 2. Оп. «Генеральное повытье». Д. 148.

20. Архив Военно-исторического музея артиллерии, инженерных войск и войск связи. Фонд 2. Оп. 8. Д. 16.

21. Архив Военно-исторического музея артиллерии, инженерных войск и войск связи. Фонд 2. Оп. 3. Д. 11.

22. Архив Военно-исторического музея артиллерии, инженерных войск и войск связи. Фонд 2. Оп. «Генеральное повытье». Д. 147.

23. Архив Военно-исторического музея артиллерии, инженерных войск и войск связи. Фонд 2. Оп. 2. Д. 20.

24. Архив Военно-исторического музея артиллерии, инженерных войск и войск связи. Фонд 2. Оп. 2. Д. 74.

25. Архив Военно-исторического музея артиллерии, инженерных войск и войск связи. Фонд 2. Оп. 3. Д. 96.

26. Архив Военно-исторического музея артиллерии, инженерных войск и войск связи. Фонд 2. Оп. 2. Д. 299. 